\title{
Large Solitary Luteinized Follicle Cyst of Pregnancy and Puerperium Newly Developed in the Postpartum
}

\author{
Hazuki Kagawa ${ }^{1}$, Tsuneko Ikeda ${ }^{2}$, Yusuke Kito $^{2}$, Hiroshi Takagi ${ }^{1}$, Satoshi Ichigo $^{1}$, Ichiro \\ Kawabata ${ }^{1}$, Kazutoshi Matsunami ${ }^{1}$, Atsushi Imai ${ }^{1 *}$ \\ ${ }^{1}$ Department of Obstetrics and Gynecology, Matsunami General Hospital, Japan \\ ${ }^{2}$ Department of Pathology, Matsunami General Hospital, Japan
}

*Corresponding author: Atsushi Imai MD PhD, Department of Obstetrics and Gynecology, Matsunami General Hospital, 185-1

Dendai, Kasamatsu, Gifu 501-6062, Japan

\section{ARTICLE INFO}

Received: 蔧 December 30, 2020

Published: 幽 January 15, 2021

Citation: Kagawa H, Ikeda T Kito Y, Imai A, et al., Large Solitary Luteinized Follicle Cyst of Pregnancy and Puerperium Newly Developed in the Postpartum. Biomed J Sci \& Tech Res 33(1)-2021. BJSTR. MS.ID.005358.

\begin{abstract}
Large solitary luteinized cyst of pregnancy and puerperium (LSLFCPP) is a rare lesion. This is characterized by a large (average $25 \mathrm{~cm}$ ), unilateral, unilocular, and rapidly growing cysts lined by the luteinized theca cells. Most of LSLFCPPs occur during pregnancy. We describe an interesting case of 35-year-old patient, gravida 3, para 3, who carried a newly developed LSLFCPP during 6-months after delivery. It exhibited rapid growth to large size to occupy the abdominal cavity. Despite low incidence of LSLFCPP, it may be critical to keep in mind when evaluating patient with large ovarian cysts even in the postpartum.
\end{abstract}

Abbreviations: LSLFCPP: Large Solitary Luteinized Cyst of Pregnancy and Puerperium; MRI: Magnetic Resonance Imaging; HCG: Human Chorionic Gonadotropin

\section{Introduction}

Ovarian tumors and tumor-like masses in the gravidpuerperium period are uncommon, with incidences ranging from 0.1 to $4.5 \%$, and an average incidence of $1 \%$ [1-3]. Non-neoplastic lesions include luteoma, ectopic decidua, hyperreaction luteinalis, hilus cell hyperplasia, granulosa cell proliferations, and large solitary luteinized cyst of pregnancy and puerperium (LSLFCPP) $[3,4]$. Among them, LSLFCPP is particularly interest in its rapid growth and enormous size [5-9]. LSLFCPP is a very rare lesion, most of which occur during pregnancy. Hence, we describe an interesting case of 35-year-old patient who had a newly developed LSLFCPP in the postpartum.

\section{Case Report}

A 35-year-old woman, gravida 3, para 3, presented to the emergency department with a history of sudden onset of pain in the lower abdomen accompanied by gradual increase in abdominal distension over 2-months period. Six months before this presentation, she had a spontaneous vaginal delivery at 40-weeks' gestation. The pregnancy advanced uneventfully, and she did not have any prenatal and antenatal abnormal abdominal mass.
On examination, the abdomen was grossly swollen. We palpated a large cystic tender mass that occupied the pelvis and extended to the sub-epigastrium. Magnetic resonance imaging (MRI) revealed a large, solitary, unilocular, and thin- and smooth-walled cystic lesion measuring 141 × 83 × $92 \mathrm{~mm}$ (Figure 1). No sold elements, septum, or mural blood flow were seen. The accompanying ascites was minimum. The patient maintained normal blood pressure and saturations, and respiratory and cardiovascular systems. Due to developing tension-like abdominal pain, she was submitted a laparotomy. We drained 4 liters of clear straw-colored fluid from the cyst and performed a right salpingo-oophorectomy.

The removed cyst was unilocular and thin-walled and contained water fluid. The outer and inner surfaces of the cyst were smooth, suggesting an intraoperative impression of a benign ovarian cyst. No frozen section was performed. The inner layer of the cyst consisted of several layers of luteinized theca cells (Figure 1). Luteinized cells were embedded in groups within fibrous tissue of the cyst wall. The pathological diagnosis was that of a large solitary luteinized follicular cyst. The patient followed the uneventful postoperative course. 


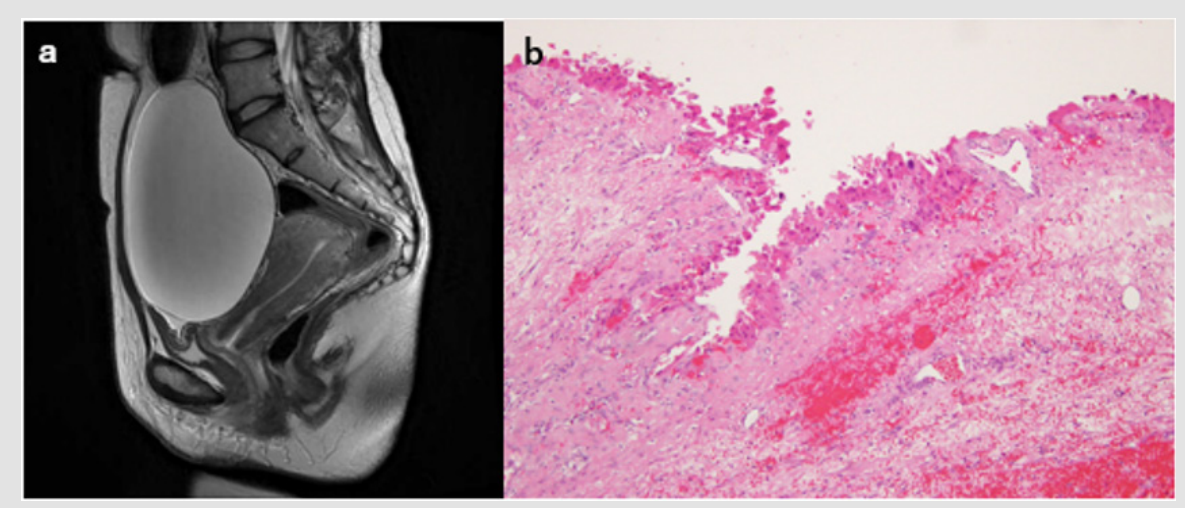

Figure 1:

(a) MR sagittal image of pelvis (T2-weighted) showing a large solitary unilocular thin-walled cyst with clear contents.

(b) Microscopic features of right ovarian cyst. The cyst is lined by several layers of luteinized theca cells showing focal marked nuclear pleomorphism (H\&E stain, x200).

\section{Comments}

Our case of LSLFCPP showed many clinicopathologic pictures similar to those described in the previous literatures [3-6]; e.g., large (average $25 \mathrm{~cm}$ ), unilateral, unilocular rapidly growing cysts and the presence of luteinized theca cells. Most LSLFCPP occur during pregnancy. The literature [5], however, has described several cases of LSLFCPP developing late in the puerperium. The etiology of LSLFCPP is unknown. Its gravid-related occurrence suggests a role of human chorionic gonadotropin (HCG) [6]. This hypothesis may be supported by the presence of large numbers of follicles, which are induced by HCG, in the residual ovaries of most cases with LSLFCPP [6,7]. The cases of LSLFCPP occurred in the postpartum when HCG levels are low may indicate that HCG only plays as one of contributing factors. Accumulating experience in cases with LSLFCPP during the postpartum will deepen our understanding of LSLFCPP. Although most patients with LSLFCPP do not show any complications, their similar clinical features of rapid grow as with malignant ovarian tumors prompted us to report the accurate diagnosis followed with adequate management. It may be critical to keep in mind when assessing patient with large ovarian cysts even in the postpartum.

\section{Disclosure Statement}

The authors declare no conflict of interest regarding the publication of this article.

\section{References}

1. Mavromatidis G, Sotiriadis A, Dinas D, Mamopoulos A, Rousso D, et al. (2010) Large luteinized follicular cyst of pregnancy. Ultrasound Obstet Gynecol 36(4): 517-520.

2. Zanetta G, Mariani E, Lissoni A, Ceruti P, Trio D, et al. (2003) A prospective study of the role of ultrasound in the management of adnexal masses in pregnancy. BJOG 110(6): 578-583.

3. Ueda M, Ueki M (1996) Ovarian tumors associated with pregnancy. Int J Gynaecol Obstet 55(1): 59-65.

4. Fang YM, Gomes J, Lysikiewicz A, Maulik D (2005) Massive luteinized follicular cyst of pregnancy. Obstet Gynecol 105(5): 1218-1221.

5. Clement PB, Scully RE (1980) Large solitary luteinized follicle cyst of pregnancy and puerperium: a clinicopathological analysis of eight cases. Am J Surg Pathol. 4(5): 431-438.

6. Lomme M, Kostadinov S, Zhang C (2011) Large solitary luteinized follicle cyst of pregnancy and puerperium: report of two cases. Diagn Pathol 6:

7. Bindra V, Taraporewalla FN, Kulkarni AD, Agrawal N (2019) Large solitary luteinized follicle cyst of pregnancy and puerperium in ruptured ectopic pregnancy managed laparoscopically. J Case Reports in Medicine 8(1): 1-5.

8. Mohan H, Chhabra S, Punia RPS, Bal A (2006) Giant solitary follicular cyst of the ovary: a case report. J Gynecol Surg 22(3): 127-130.

9. Mavromatidis G, Sotiriadis A, Dinas K, Mamopoulos A, Rousso D, et al. (2010) Large luteinized follicular cyst of pregnancy. Ultrasound Obstet Gynecol 36(4): 517-520. 
ISSN: 2574-1241

DOI: 10.26717/BJSTR.2021.33.005358

Martin P Stewart. Biomed J Sci \& Tech Res

(C) This work is licensed under Creative

Submission Link: https://biomedres.us/submit-manuscript.php

$\begin{array}{ll}\text { BIOMEDICAL } & \text { Assets of Publishing with us } \\ \text { RESEARCHES } & \text { - Global archiving of articles } \\ \text { - Immediate, unrestricted online access } \\ \text { - Rigorous Peer Review Process }\end{array}$

